\title{
WEB CONTENT MINING DI SEKTOR PERBANKAN PADA LQ45 UNTUK PENDUKUNG KEPUTUSAN INVESTASI SAHAM
}

\author{
Nehu Chandra Citra Ayu Phitaloka (1), Dessyanto Boedi Prasetyo (2), Rifki Indra Perwira (3) \\ Jurusan Teknik Informatika Fakultas Teknik Industri UPN “Veteran” Yogyakarta \\ Jl. Babarsari 2 Tambakbayan Yogyakarta \\ e-mail : nehuayuu@gmail.com ${ }^{(1)}$, dessyanto@upnyk.ac.id(2), rifki@upnyk.ac.id(3)
}

\begin{abstract}
Investment is an activity that is very financially profitable, and also an activity that has a high risk. The investment process includes understanding the basics of investment decisions and how to organize activities in the decision-making process. In the world of investment business, especially stocks, price information can change rapidly depending on offers that occur on the trading floor and other aspects which are also very influential. Information in the form of stock news with web content mining is one of the fundamental analyzes. Web content mining utilizes crawling as the content of news content. News content is done by taking content from the website detik.com, cnnindonesia.com, and kontan.co.id. The research methodology used is waterfall. The results of the study are able to provide convenience in making stock investment decisions. Ease in this case is the process when the user can directly analyze using fundamental analysis on an investment decision support system.
\end{abstract}

\section{Keywords: Decision Support, Fundamental Analysis, Web Content Mining, Crawling}

\begin{abstract}
Abstrak
Investasi merupakan suatu kegiatan yang sangat menguntungkan secara finansial, dan juga merupakan kegiatan yang mempunyai resiko tinggi. Proses investasi meliputi pemahaman dasar-dasar keputusan investasi dan bagaimana mengorganisir aktifitas-aktifitas dalam proses pengambilan keputusan. Dalam dunia bisnis investasi khususnya saham, informasi harga bisa berubah dengan cepat tergantung penawaran yang terjadi di lantai bursa dan juga aspek-aspek lain yang juga sangat berpengaruh. Informasi berupa berita saham dengan web content mining merupakan salah satu analisis fundamental. Web content mining memanfaatkan crawling sebagai pengambilan isi konten berita. Konten berita dilakukan dengan mengambil isi konten dari website detik.com, cnnindonesia.com, dan kontan.co.id. Metodologi penelitian yang digunakan yaitu waterfall. Hasil dari penelitian yaitu mampu memberikan kemudahan dalam mengambil keputusan investasi saham. Kemudahan dalam hal ini adalah proses pada saat pengguna bisa menganalisis secara langsung menggunakan analisis fundamental pada sebuah sistem pendukung keputusan investasi.
\end{abstract}

Kata Kunci : Pendukung Keputusan, Analisis Fundamental, Web Content Mining, Crawling

\section{PENDAHULUAN}

\subsection{Latar Belakang Masalah}

Investasi merupakan suatu kegiatan yang sangat menguntungkan secara finansial, dan juga merupakan kegiatan yang mempunyai resiko tinggi (Handoko, 2009). Dalam investasi saham terdapat dua analisis yang dilakukan yaitu analisis teknikal dan analisis fundamental. Analisis fundamental adalah studi tentang ekonomi, industri, dan kondisi perusahaan untuk memperhitungkan nilai dari saham perusahaan (Artha, 2014).

Analisis teknikal adalah teknik untuk memprediksi arah pergerakan saham dan indikator pasar saham lainnya berdasarkan pada data historis. Analisis teknikal merupakan metode meramalkan pergerakan harga saham dan kecenderungan pasar di masa mendatang dengan cara mempelajari grafik harga saham, volume perdagangan, dan indeks harga saham gabungan. Analisis fundamental jarang dilakukan oleh investor yang berinvestasi untuk jangka pendek. Analisis fundamental digunakan oleh para investor yang berinvestasi untuk jangka waktu panjang (Harwaningrum, 2016). 
Para investor yang terjun ke dunia saham tentu memiliki dasar pertimbangan sebelum akhirnya membeli emiten tertentu, yaitu dengan analisis teknikal dan analisis fundamental. Salah satu yang sering digunakan untuk para pemula (investor baru) adalah analisis fundamental, dimana investor melihat laporan keuangan dan fundamental perusahaan dari berita maupun artikel. Tetapi pada kenyataannya investor baru masih memiliki keraguan untuk pengambilan keputusan investasi. Padahal Bursa Efek Indonesia sedang mencanangkan program "Yuk Menabung Saham" untuk para generasi milenial di Indonesia saat ini. Generasi milenial diharapkan ikut serta meramaikan pasar modal Indonesia sekaligus berinvestasi saham sebagai tabungan di masa depan. Karena investasi saham bisa dilakukan dimana saja dan kapan saja, investasi saham juga bisa menjadi investasi jangka panjang yang menguntungkan.

Sebagian besar investor baru ini lebih memilih untuk melihat berita-berita mengenai pasar modal dan saham dari media elektronik yang telah tersedia di internet. Berita-berita tersebut mengandung rekomendasi pembelian saham, prediksi saham dalam waktu dekat, nilai IHSG, tips-tips investasi maupun saham-saham yang cenderung menguat atau melemah.

Maka dari itu, ditawarkan sebuah solusi untuk membuat sistem web content mining dimana sistem ini dapat mengambil berita-berita tentang saham sesuai dengan masukan emiten yang dipilih oleh pengguna. Dalam sistem ini dibatasi hanya sektor perbankan pada LQ45 saja, yaitu kode-kode sahamnya adalah BBRI, BMRI, BBNI, BBCA, BBTN, dan BJBR. LQ45 adalah indeks pasar saham di Bursa Efek Indonesia (BEI) yang terdiri dari 45 emiten yang memenuhi kriteria tertentu. Sedangkan untuk berita saham diambil dari tiga website tertinggi pilihan investor baru sesuai dengan hasil survei dan wawancara yaitu detik.com, cnnindonesia.com, dan kontan.co.id. Yang mana sistem akan mengintegrasikan Web Content Mining sebagai penyaringan berita dari situs-situs, pada Web Content Mining menggunakan Crawling untuk mengambil berita-berita saham. Hasil analisis web Content Mining berupa link beserta isi konten berita yang sudah di saring mengenai saham dari tiga website detik.com, cnnindonesia.com, kontan.co.id. Sistem akan memberikan informasi gratis kepada pengguna nya sehingga bisa menganalisa dan siap mengambil keputusan pembelian saham emiten tertentu sebelum pembukaan rekening efek di sekuritas. Hal tersebut diharapkan mampu menyelesaikan masalah mengenai keputusan dalam investasi saham analisis fundamental.

\subsection{Rumusan Masalah}

Berdasarkan latar belakang masalah tersebut, maka rumusan masalah yang dapat diambil adalah sebagai berikut:

1. Bagaimana sistem dapat memudahkan investor baru dalam pengambilan keputusan pembelian saham dan informasi fundamental suatu emiten.

2. Bagaimana sistem menyaring berita saham suatu emiten tertentu dengan web content mining untuk menemukan pola kecenderungan berita.

\subsection{Tujuan Penelitian}

Berdasarkan rumusan masalah yang telah diuraikan diatas, maka tujuan penelitian yaitu:

1. Memberikan kemudahan untuk investor baru dalam mengambil keputusan investasi saham jangka panjang.

2. Mengimplementasikan web content mining sebagai salah satu analisis fundamental pendukung keputusan pembelian saham.

\subsection{Tinjauan Pustaka}

Adapun penelitian yang dilakukan sebelumnya ada beberapa variasi dan keunggulan masingmasing, berikut penelitian sebelumnya diantaranya:

a. Penelitian yang dilakukan oleh (Zuliarni, 2012) dengan judul Pengaruh Kinerja Keuangan Terhadap Harga Saham Pada Perusahaan Mining And Mining Service Di Bursa Efek Indonesia dimana sistem ini menganalisis pengaruh kinerja keuangan perusahan mining dan mining service menggunakan metode regresi linear. Pada hasil pengujian, Return On Assets (ROA), Price Earning Ratio (PER) dan Dividend Payout Ratio (DPR) berpengaruh terhadap harga saham.

b. Penelitian yang dilakukan oleh (Kristanto, 2008) dengan judul Sistem Pendukung Keputusan Investasi Saham Berbasis pada Analisis Kualitatif dari Berita Bursa 
Saham, Analisis Fundamental dan Teknikal dimana sistem ini melakukan pembangunan suatu prototipe perangkat Sistem Pendukung Keputusan (SPK) yang mampu mengakses secara online beberapa situs yang dibutuhkan untuk pemasukan data fundamental saham, data teknikal dan berita-berita saham.

c. Penelitian yang dilakukan oleh (Yuliansyah, 2008) dengan judul Penerapan Web Content Mining Untuk Menentukan Pola Kecenderungan Berita dimana sistem ini menggali dan menyajikan data secara otomatis dengan menemukan dan menghasilkan informasiinformasi dari sumber online atau dokumen web yang tersedia kemudian melakukan perhitungan untuk menemukan pola kecenderungan berita.

d. Penelitian yang dilakukan oleh (Thoriq, 2015) dengan judul Web Content Mining Menggunakan Partitional Clustering K-Means Pada News Aggregator dimana sistem ini mengolah news aggregator agar dapat menampilkan informasi berita yang sesuai dengan pencarian pengguna. Sistem ini akan menghimpun berita dari situs berita Tribun, Republika, dan Kompas. Menggunakan pendekatan partitional clustering untuk pengelompokkan berita-berita dengan topik yang sama.

\section{METODOLOGI PENELITIAN}

Metodologi yang digunakan dalam penelitian ini yaitu terdiri dari metode pengumpulan data metode kualitatif dan metode pengembangan sistem waterfall. Penelitian ini dilakukan di Bursa Efek Yogyakarta dengan menambah referensi wawancara di Sinarmas Sekuritas dan kuesioner di Fakultas Ekonomi dan Bisnis Universitas Pembangunan Nasional "Veteran" Yogyakarta.

Metode pengembangan sistem yang digunakan dalam penelitian ini adalah metode waterfall (Pressman, 2012). Metode air terjun atau yang sering disebut metode waterfall sering dinamakan siklus hidup klasik (classic life cycle), dimana hal ini menggambarkan pendekatan yang sistematis dan juga berurutan pada pengembangan perangkat lunak, dimulai dengan spesifikasi kebutuhan pengguna lalu berlanjut melalui tahapan-tahapan perencanaan (planning), permodelan (modeling), konstruksi (construction), serta penyerahan sistem ke para pelanggan/pengguna (deployment), yang diakhiri dengan dukungan pada perangkat lunak lengkap yang dihasilkan (Buani, 2014).

\subsection{Pengumpulan Data}

Proses pengumpulan data memiliki beberapa tahapan. Tahapan analisis masalah pada penelitian ini berupa wawancara, kuisioner dan studi pustaka. Analisis masalah dilakukan wawancara dengan broker dan karyawan Sinarmas Sekuritas, investor baru dan karyawan Bursa Efek Yogyakarta dan investor muda Fakultas Ekonomi dan Bisnis Universitas Pembangunan Nasional "Veteran" Yogyakarta. Beberapa hal dalam wawancara dan juga pembagian kuisioner secara mendapatkan suatu masalah dimana para investor baru kesulitan dalam menganalisa saham suatu emiten dengan analisis teknikal dan fundamental serta ragu untuk membuat keputusan investasi saham.

\subsection{Analisis Kebutuhan Aplikasi}

Tahap analisis dilakukan dengan menganalisis sistem yang dibutuhkan dalam pendukung keputusan investasi saham jangka panjang. Tahapan analisis kebutuhan meliputi :

1. Analisis data harga saham close

2. Identifikasi masalah

3. Analisis sistem

\subsection{Perancangan Sistem}

Perancangan sistem terdiri dari flowchart, entity relationship diagram (ERD), dan data flow diagram (DFD).

\subsubsection{Flowchart Web Content Mining}

Tahapan proses web content mining dilakukan dengan beberapa proses dimulai dari menginputkan data kode perusahaan kemudian memasukan referensi link yang akan di 
crawling website nya setelah itu melakukan koneksi ke module.php dan melakukan proses dengan library simple html dom (Yuliansyah, 2008). Proses web content mining dapat dilihat pada gambar 1 .

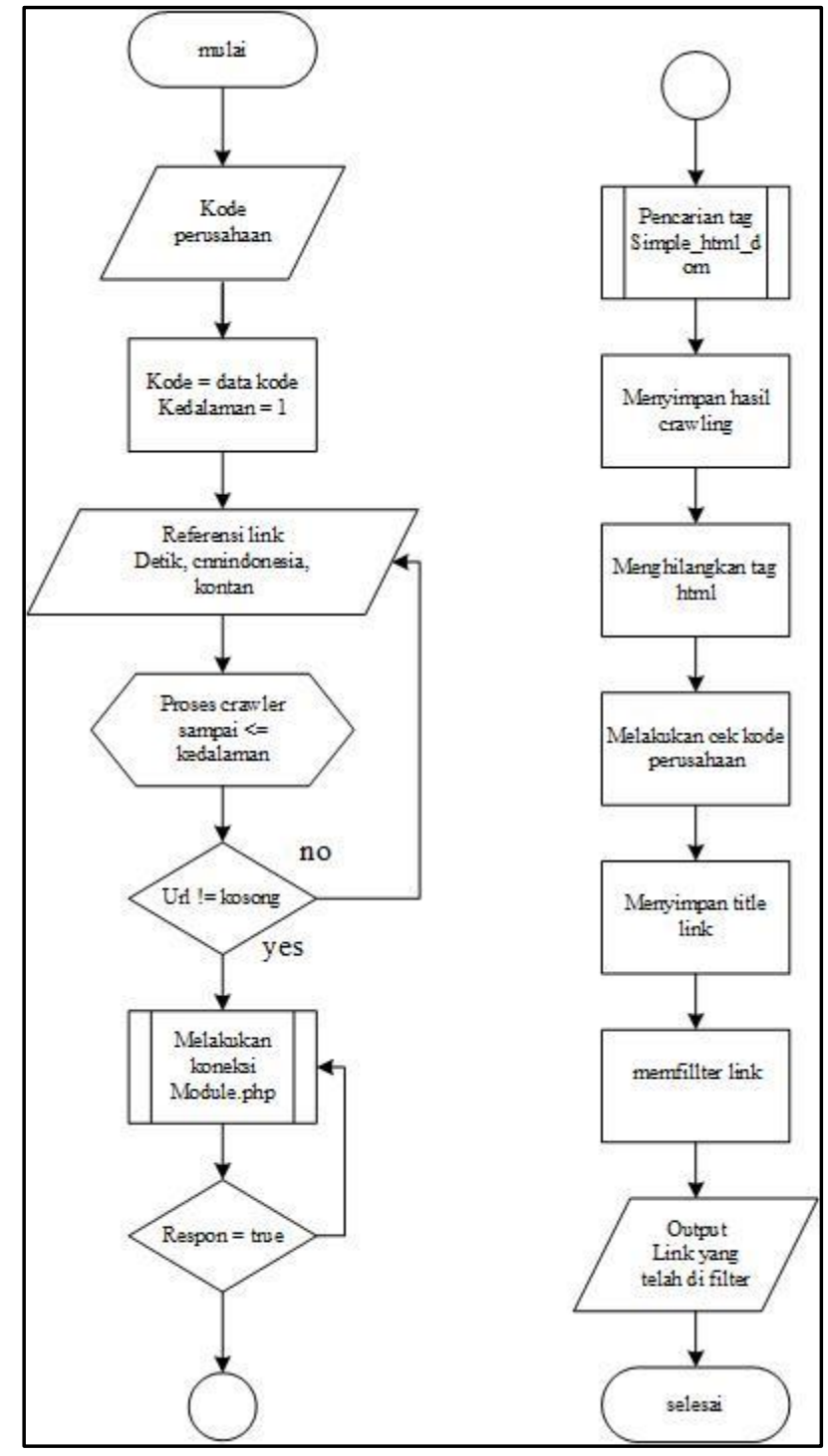

Gambar 1. Proses Web Content Mining

Proses Web Content Mining di mulai dengan memasukan kode perusahaan yang sebelumnya sudah ada di dalam database lalu menginisialisasikan kode dengan data kode dalam database kemudian membuat kondisi variabel kedalaman sama dengan satu. Dimana kedalaman ini berfungsi untuk mengambil data dengan kedalaman satu. Lalu memasukan referensi link website yaitu detik.com, cnnindonesia.com, dan kontan.co.id sebagai referensi yang akan diambil datanya.

\subsubsection{Data Flow Diagram (DFD)}

Diagram level 0 merupakan diagram yang menggambarkan garis besar keseluruhan alur proses hubungan antar sistem dengan entitas dari luar yang mempengaruhi sistem. DFD level 0 juga disebut dengan diagram konteks yang terdiri dari satu lingkaran besar yang dapat mewakili seluruh proses yang terdapat di dalam suatu sistem. DFD level 0 dapat dilihat pada gambar 2. 


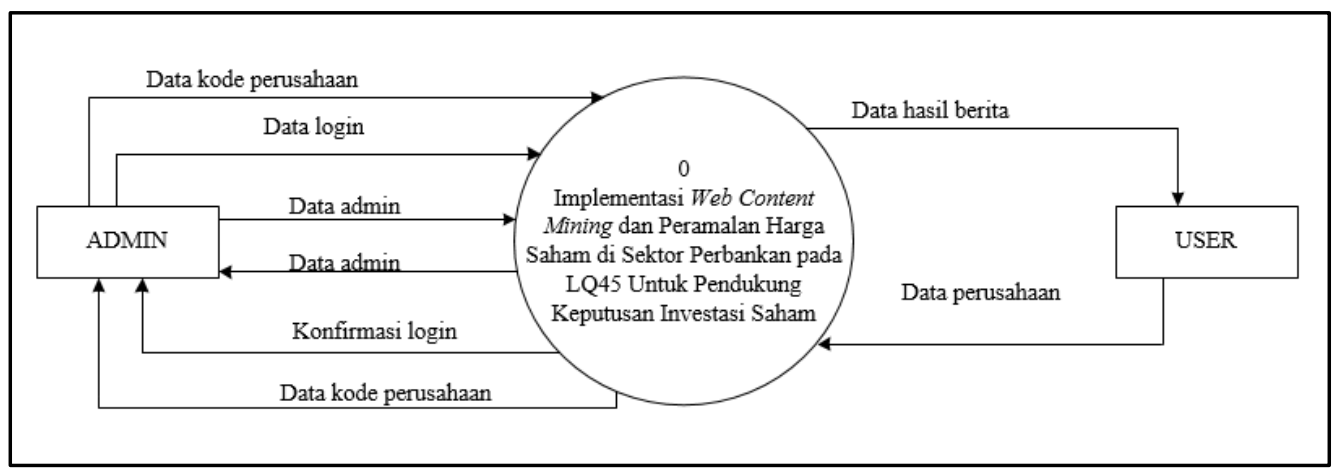

Gambar 2. DFD Level 0

DFD level 1 menggambarkan turunan proses dari DFD level 0. Diagram ini akan menampilkan penjabaran secara detail proses dari DFD level 0 yang terdapat entitas, proses, data dan seluruh aliran data yang terjadi pada sistem. DFD level 1 dapat dilihat pada gambar 3.

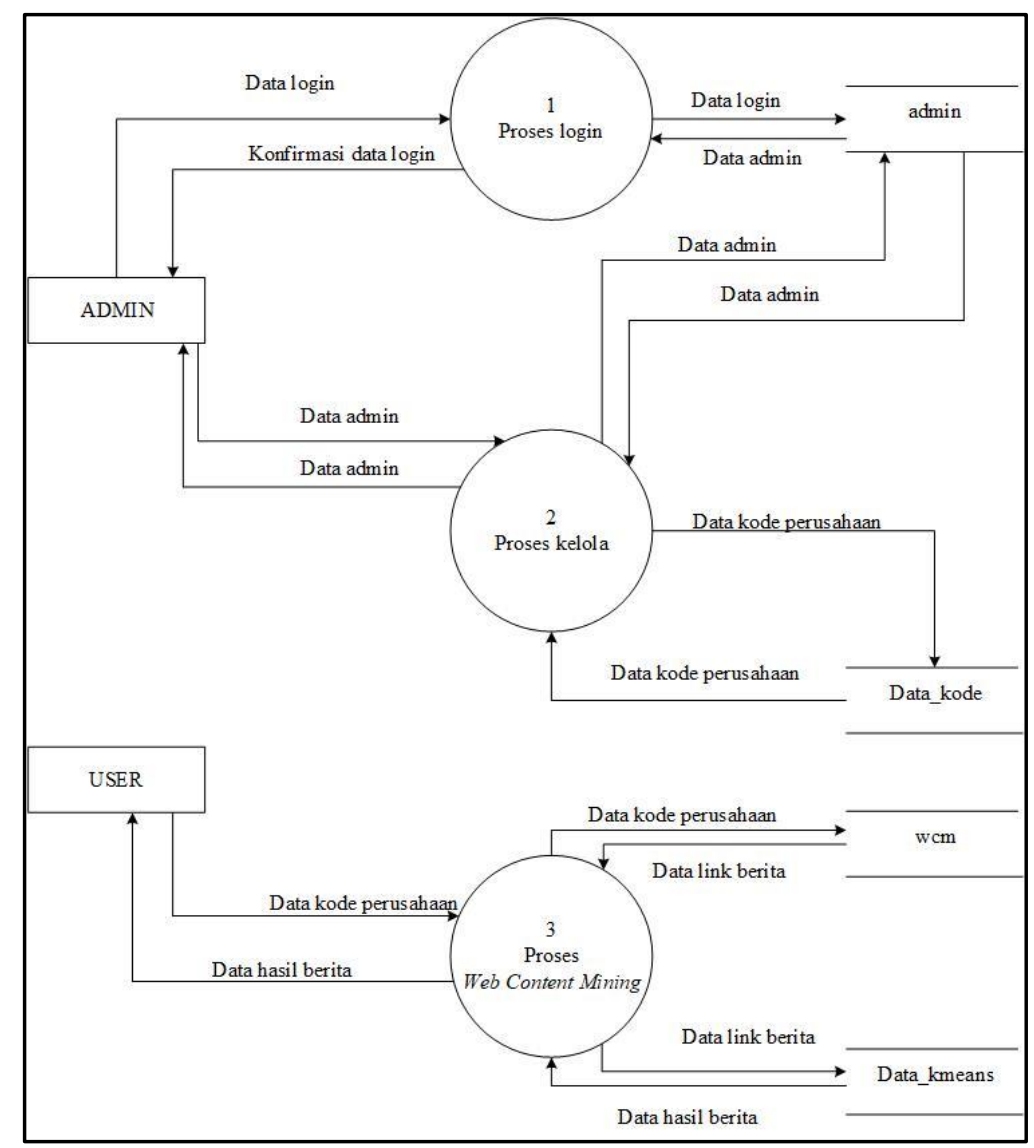

Gambar 3. DFD Level 1

\subsubsection{Entity Relationship Diagram (ERD)}

Entity Relationship Diagram (ERD) merupakan beberapa entitas yang berelasi dalam suatu database berdasarkan hubungan entitas yang ditentukan oleh atribut-atributnya. Rancangan database utuk sistem yang akan dihasilkan terdapat beberapa entitas yang saling berelasi (Sari, 2018). Entity Relationship Diagram dapat dilihat pada gambar 4. 


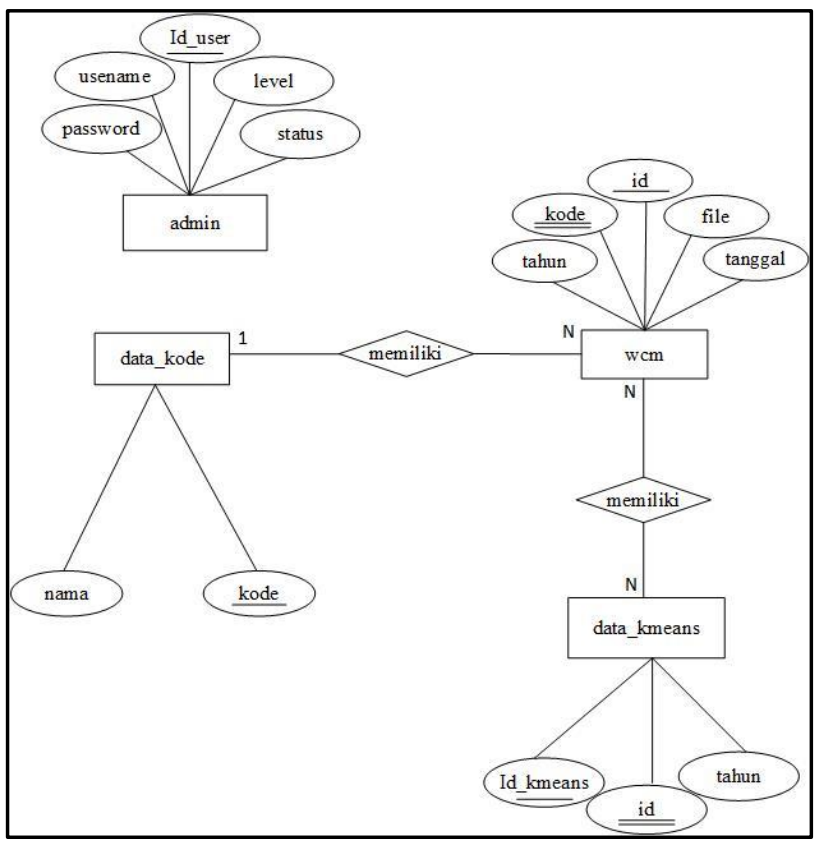

Gambar 4. ERD

\section{HASIL DAN PEMBAHASAN}

Hasil dari penelitian ini adalah membuat sistem untuk mendukung keputusan investasi saham jangka panjang dengan peramalan harga saham sebagai salah satu analisis teknikal dan web content mining dengan menyaring berita-berita saham sebagai salah satu analisis fundamental.

\subsection{Halaman Web Content Mining}

Tampilan hasil web content mining ditampilkan pada saat proses pencarian (crawling) perusahaan pada halaman web content mining telah selesai dilakukan. Sistem akan menampilkan hasil dari sekumpulan berita dari beberapa website mengenai perusahaan yang sebelumnya dipilih. Halaman web content mining dapat dilihat pada gambar 5.

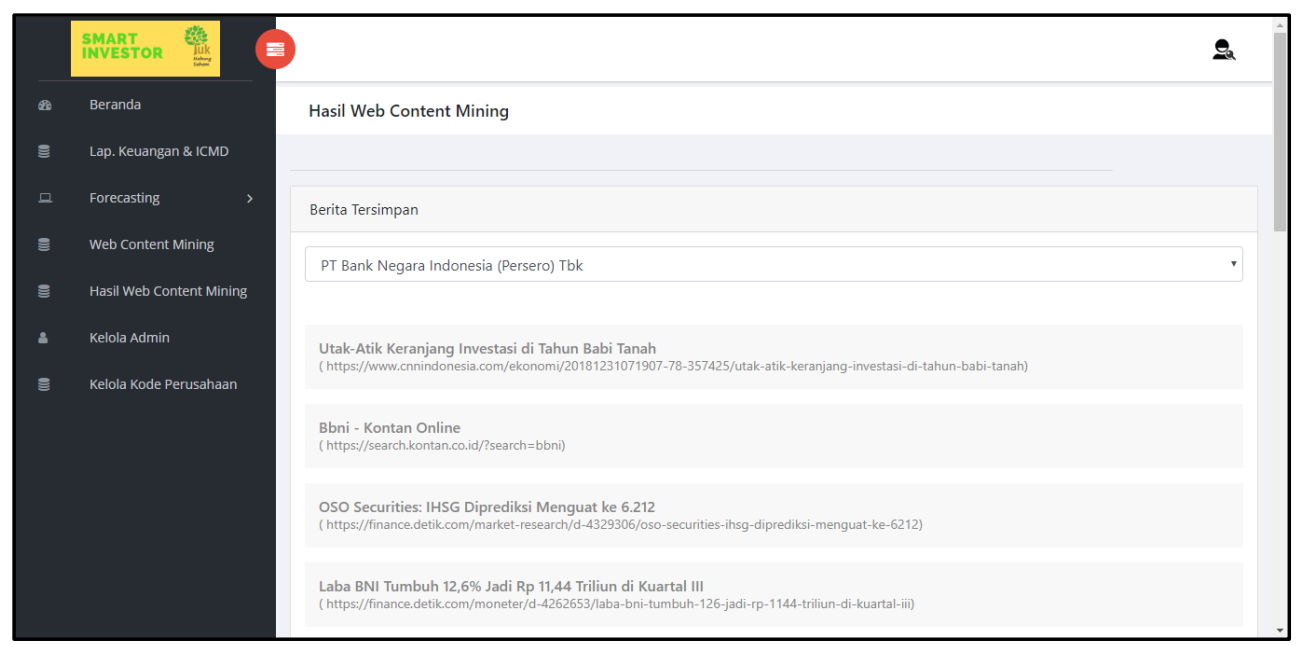

Gambar 5. Halaman Hasil Web Content Mining

Tampilan isi berita akan muncul saat salah satu berita dari hasil web content mining dipilih. Pada gambar 6 terdapat beberapa pilihan berita yang hanya menampilkan judul dan alamat 
berita tersebut, setelah dipilih kemudian akan menampilkan halaman isi berita. Halaman isi berita dapat dilihat pada gambar 6 .

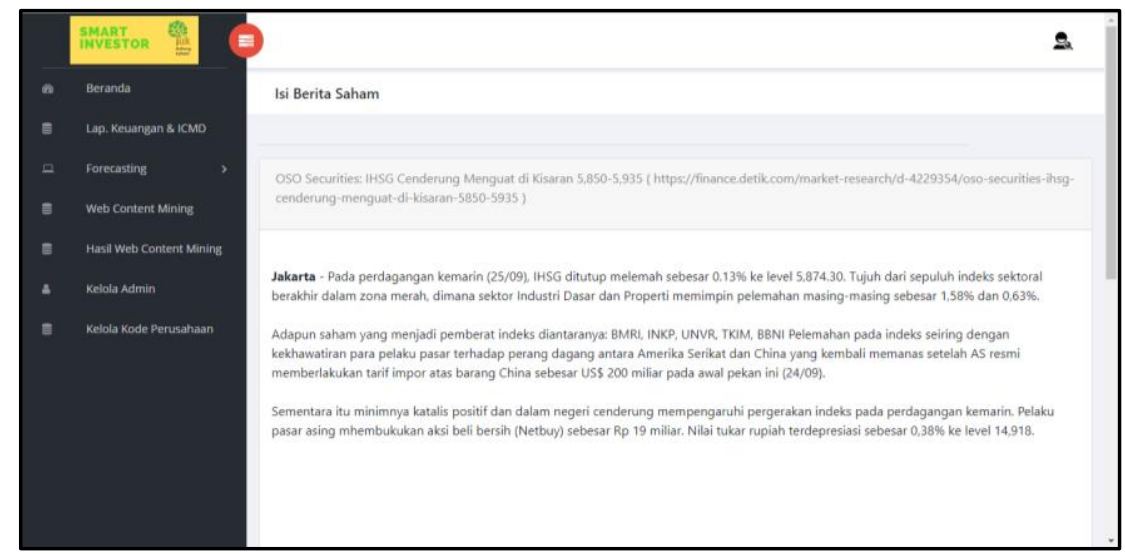

Gambar 6. Halaman Isi Berita

\subsection{Arsitektur Web Content Mining}

Web crawler adalah sebuah sistem yang menjelajahi struktur hyperlink dari web, dari sebuah alamat awal atau seed dan mengunjungi alamat web di dalam webpage secara berkala. Search engine yang merupakan salah satu contoh sistem besar yang menggunakan crawler untuk melintasi internet secara terus-menerus dengan tujuan menemukan dan mengambil webpage sebanyak mungkin. Proses yang dilakukan yaitu pertama mengunduh webpage nya terlebih dahulu kemudian melakukan parsing webpage yang sudah diunduh dan mengambil link, lalu mengulangi proses untuk setiap web yang diambil (Thoriq, 2015). Arsitektur web content mining dapat dilihat pada gambar 7 .

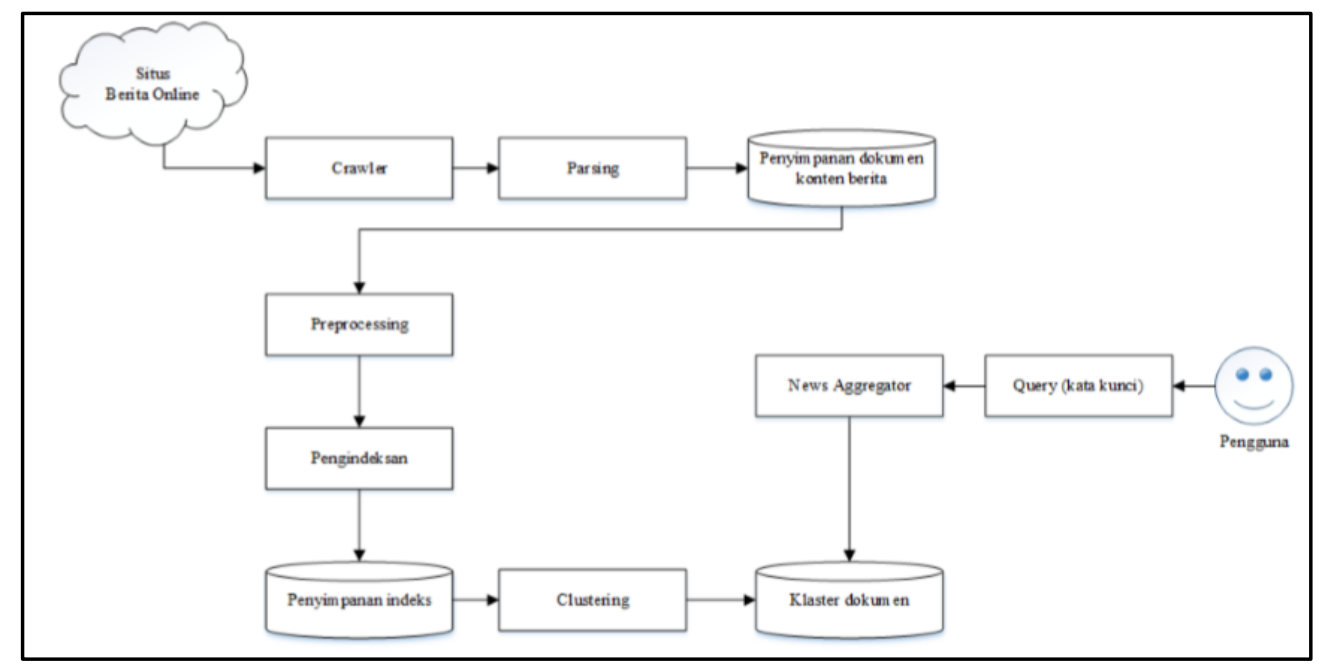

Gambar 7. Arsitektur Web Content Mining

\subsection{Pengujian Black Box}

Pengujian pada penelitian ini merupakan pengujian pada website. Pengujian website ini berfokus pada spesifikasi fungsional dari perangkat lunak. Pada pengujian black box akan dilakukan pengamatan hasil dari eksekusi pada website tersebut. Tujuan dari pengujian ini yaitu untuk mencari dan mengetahui kesalahan yang terjadi pada aplikasi sehingga dapat dilakukan perbaikan. Pengujian akan menjadi acuan dalam pengembangan pada antarmuka website. 


\subsubsection{Pengujian Alpha Test}

Pengujian dilakukan oleh responden yang akan menguji dengan menjalankan setiap fungsi yang telah dijabarkan pada setiap poin pengujian. Penilaian dilakukan dengan menentukan skala penilaian yang akan diisi berdasarkan kesesuaian dari hasil pengujian. Skala penelitian yang digunakan yaitu nilai " $5 / 5$ " yang berarti hasil penilaian dari lima responden dapat berjalan dengan baik karena setiap fungsi pada aplikasi telah sesuai dengan poin-poin yang ada. Pengujian Alpha Test dapat dilihat pada tabel 1.

Tabel 1. Tabel Alpha Test Pada Admin

\begin{tabular}{|c|c|c|c|c|}
\hline \multicolumn{5}{|c|}{ Halaman Admin } \\
\hline \multirow[t]{2}{*}{ No } & \multirow[t]{2}{*}{ Detail Item } & \multirow[t]{2}{*}{ Detail Pengujian } & \multicolumn{2}{|c|}{ Penilaian } \\
\hline & & & Ya & Tidak \\
\hline 1. & Halaman Beranda & $\begin{array}{l}\text { Melihat kesesuaian tampilan } \\
\text { halaman utama }\end{array}$ & $5 / 5$ & \\
\hline \multirow{4}{*}{2.} & \multirow{4}{*}{$\begin{array}{l}\text { Halaman Data } \\
\text { Saham }\end{array}$} & Keberhasilan proses tambah data & $5 / 5$ & \\
\hline & & Keberhasilan proses ubah data & $5 / 5$ & \\
\hline & & Keberhasilan proses hapus data & $5 / 5$ & \\
\hline & & Kembali ke tabel data & $5 / 5$ & \\
\hline \multirow{4}{*}{3.} & \multirow{4}{*}{$\begin{array}{l}\text { Halaman Kelola } \\
\text { Admin }\end{array}$} & Keberhasilan proses tambah data & $5 / 5$ & \\
\hline & & Keberhasilan proses ubah data & $5 / 5$ & \\
\hline & & Keberhasilan proses hapus data & $5 / 5$ & \\
\hline & & Kembali ke tabel data & $5 / 5$ & \\
\hline 4. & $\begin{array}{l}\text { Halaman Berita } \\
\text { saham }\end{array}$ & $\begin{array}{l}\text { Kesesuaian dalam menentukan } \\
\text { berita saham }\end{array}$ & $5 / 5$ & \\
\hline \multirow{4}{*}{5.} & \multirow{4}{*}{$\begin{array}{l}\text { Halaman Kelola } \\
\text { Kode Perusahaan }\end{array}$} & Keberhasilan proses tambah data & $5 / 5$ & \\
\hline & & Keberhasilan proses ubah data & $5 / 5$ & \\
\hline & & Keberhasilan proses hapus data & $5 / 5$ & \\
\hline & & Kembali ke tabel data & $5 / 5$ & \\
\hline \multicolumn{5}{|c|}{ Halaman User } \\
\hline \multirow[t]{2}{*}{ No } & \multirow[t]{2}{*}{ Detail Item } & \multirow[t]{2}{*}{ Detail Pengujian } & \multicolumn{2}{|c|}{ Penilaian } \\
\hline & & & Ya & Tidak \\
\hline 1. & Halaman Beranda & $\begin{array}{l}\text { Melihat kesesuaian tampilan } \\
\text { halaman utama }\end{array}$ & $5 / 5$ & \\
\hline 2. & $\begin{array}{l}\text { Halaman Data } \\
\text { Saham }\end{array}$ & Kesesuain laporan keuangan & $5 / 5$ & \\
\hline 3. & $\begin{array}{l}\text { Halaman Berita } \\
\text { Saham }\end{array}$ & $\begin{array}{l}\text { Kesesuain berita saham dengan } \\
\text { perusahaannya }\end{array}$ & $5 / 5$ & \\
\hline
\end{tabular}

\subsubsection{Pengujian Beta Test}

Pengujian beta adalah pengujian yang dilakukan oleh pemakai oleh lingkungan pemakai, dimana lingkungan perangkat lunak tidak lagi dapat dikendalikan oleh pengembang. Pengujian beta merupakan pengujian yang dilakukan secara objektif secara langsung ke lapangan dengan menggunakan kuesioner mengenai tanggapan pengguna terhadap sistem pendukung keputusan investasi saham. Pada pengujian dari 10 responden ini menghasilkan kesimpulan bahwa aplikasi dapat berjalan dengan baik walaupun 1 responden mengatakan ragu-ragu pada pernyataan nomer 6 . Pengujian Beta Test dapat dilihat pada tabel 2.

Tabel 2. Tabel Pengujian Beta Test

\begin{tabular}{|r|l|c|c|c|c|c|}
\hline \multirow{2}{*}{ No } & \multicolumn{2}{|c|}{ Item Uji } & \multicolumn{4}{c|}{ Penilaian } \\
\cline { 3 - 6 } & & SS & S & RR & TS & STS \\
\hline 1. & Aplikasi memiliki tampilan yang mudah digunakan & $1 / 10$ & $9 / 10$ & & & \\
\hline 2. & Aplikasi mudah dioperasikan oleh user (pengguna) & $3 / 10$ & $7 / 10$ & & & \\
\hline 3. & Aplikasi sesuai dengan kebutuhan user & $10 / 10$ & & & & \\
\hline
\end{tabular}




\begin{tabular}{|r|l|c|c|c|c|c|}
\hline \multirow{2}{*}{ No } & \multicolumn{1}{|c|}{ Item Uji } & \multicolumn{5}{c|}{ Penilaian } \\
\cline { 3 - 7 } & \multicolumn{1}{|c|}{ SS } & S & RR & TS & STS \\
\hline 4. & Tampilan aplikasi sesuai dengan kebutuhan user & $9 / 10$ & $1 / 10$ & & & \\
\hline 5. & $\begin{array}{l}\text { Hasil dari berita saham sesuai dengan kode perusahaan } \\
\text { yang dicari }\end{array}$ & $10 / 10$ & & & & \\
\hline 6. & Hasil peramalan mudah di mengerti oleh user & $2 / 10$ & $7 / 10$ & $1 / 10$ & & \\
\hline 7. & $\begin{array}{l}\text { Informasi laporan keuangan mudah di unduh dan } \\
\text { digunakan }\end{array}$ & $10 / 10$ & & & & \\
\hline
\end{tabular}

\section{KESIMPULAN}

Berdasarkan dari hasil analisis, perancangan dan pembahasan yang telah dilakukan sebelumnya, maka dapat dihasilkan sebuah sistem pendukung keputusan untuk investasi jangka panjang menggunakan web content mining dan peramalan. Kesimpulan yang dapat diambil dari penelitian ini antara lain:

1. Memberikan kemudahan dalam mengambil keputusan investasi saham menggunakan analisis fundamental.

2. Crawling web content mining dapat diimplentasikan dengan mengambil berita-berita saham terkini dengan tiga website.

Penelitian yang telah dilakukan memiliki beberapa acuan yang telah dicapai yang dapat terlihat dalam kesimpulan. Disamping adanya pencapaian tersebut sistem ini masih memerlukan adanya pengembangan. Beberapa hal yang dapat diterapkan untuk pengembangan sistem lebih lanjut yaitu pada penelitian ini perlu adanya pengembangan dengan analisis perbandingan semua sektor saham, nilai-nilai dividen, capital market, earning per share dan lain-lain pada laporan keuangan diharapkan mampu menjadi salah satu analisis peramalan di gabung dengan harga saham serta pengembangan mengenai berita saham di lakukan secara realtime tanpa harus melakukan proses searching di sistem.

\section{DAFTAR PUSTAKA}

Artha, D. R. (2014). Analisis Fundamental, Teknikal Dan Makroekonomi. Jurnal Manajemen Dan Kewirausahaan, 16(2), 175-183. https://doi.org/10.9744/jmk.16.2.175

Buani, D. C. P. (2014). PERANCANGAN SISTEM INFORMASI AKADEMIK DENGAN MENGGUNAKAN METODE WATERFALL STUDI KASUS AL MUALLAFAH ISLAMIC SCHOOL. In Seminar Nasional Ilmu Pengetahuan dan Teknologi Komputer (Vol. 2, hal. 202-209).

Handoko, T. (2009). Sistem Pendukung Keputusan Signal Jual Beli Saham Dnegan Menggunakan Metode Williams \%R dan Geometric Moving Average. Jurnal EKSIS, 2(1), 22-28.

Harwaningrum, M. (2016). Perbandingan Penilaian Saham Dengan Metode Analisis Fundamental Dan Analisis Tehknical, Penggorengan Saham, Untuk Kedua Metode Analisis Pada Saham Bakrie Group, 2(2010), 138-149.

Kristanto, N. H. (2008). Sistem Pendukung Keputusan Investasi Saham Berbasis pada Analisis Kualitatif dari Berita Bursa Saham, Analisis Fundamental dan Teknikal.

Pressman, R. S. (2012). Rekayasa Perangkat Lunak: Pendekatan Praktisi. Andi.

Thoriq, N. I. (2015). Web Content Mining Menggunakan Partitional Clustering K-Means Pada News Aggregator, 5(2), 42-46.

Yuliansyah, I. (2008). PENERAPAN WEB CONTENT MINING UNTUK MENEMUKAN POLA KECENDERUNGAN BERITA.

Zuliarni, S. (2012). Pengaruh Kinerja Keuangan Terhadap Harga Saham Pada Perusahaan Mining And Mining Service Di Bursa Efek Indonesia. Jurnal Aplikasi Bisnis, 3(1), 36-48. https://doi.org/10.1021/jp014572x 